\title{
Potential of Protease from Bacillus species for Biomedical and Industrial Applications
}

\author{
Jitendra Malviya* \\ Department of Life Science and Biological Sciences IES University, Bhopal, M.P., India \\ *Corresponding author
}

\section{A B S T R A C T}

\section{Keywords}

Protease, microbes, Bacillus species,

Proteolytic,

Hydrolysis,

Medicinal,

Industrial

Applications

Article Info

Accepted:

22 April 2021

Available Online:

10 May 2021
The aim of the study to provide basic potential of protease from bacillus species for diverse application biomedical as well as industrial use has been reported. Total 46 research article have been selected for the study and read out and make out a list of various industrial applications are screened under alkaline protease \& industry, protein hydrolysis, food and feed industry, cowhide industry, cleasner, Photographic industry, element industry, silk degumming and clinical trials. Proteases expected for present day applications should have activity and relentlessness over wide extent of temperature and $\mathrm{pH}$ limits for postponed time periods and even inside seeing distinctive likely synthetic inhibitors. Of various microbial proteases those from Bacillus spp. have exceptional vitality considering the way that the last are known for their ability to convey sturdy synthetic substances that may have fittingness for current system conditions. The current article presents an interpretive layout of the progressing headways on application ability of proteases for various organizations.

\section{Introduction}

Proteases have been successfully made by researchers from different microbial sources. Microorganisms account a $66 \%$ bit of business protease all throughout the planet (Beg and Gupta, 2003). Since the presence of enzymology, microbial proteolytic proteases have been the most extensively thought about protein. These mixtures have gotten interest not in light of their basic occupation in metabolic activities yet likewise due to their tremendous utilization in adventures (Rao et al., 1998; Sandhya et al., 2005; Younes and Rinaudo, 2015). The proteases open in the market are of microbial beginning stage because of their exceptional yield, less time use, less space essential, fabulous innate control, and cost-ampleness, which have made them proper for biotechnological application 
on the lookout (Nisha and Divakaran, 2014; Ali et al., 2016). These microbial proteases are gotten a kick out of the chance to plant and animal proteases considering the proximity of each and every needed brand name for mechanical applications (Palsaniya et al., 2012). Proteolytic mixtures found in organic entities and mammalian structures are minimal in size, thick, and in a general sense round. Among different creators of solvent proteases, Bacillus sp. is basic (Rifaat et al., 2007). The proteases separated from these microbial sources have a gigantic number of weakenings in various mechanical territories (Das and Prasad, 2010). Regularly, extracellular solvent proteases are released out from the creator into the liquid juices from where these proteases are adjusted and sifted through down spilling to convey a completed outcome. Generally, proteases conveyed by plants and animals are more work genuine than microbially conveyed proteases (Gupta et al., 2002; Kalaiarasi and Sunitha, 2009). Proteases made by microbial sources are described into bundles reliant on their acidic or central properties. They are also requested subject to the proximity of valuable get-togethers and the circumstance of peptide bond (Panda et al., 2013).

Microbial proteases are the most fiscally abused protein all throughout the planet. A colossal number of intracellular proteases are made by microorganisms accepting an essential occupation in detachment, protein turnover, chemical rule, and cell protein pool, while extracellular proteases are vital in protein hydrolysis (Adrio and Demain, 2014, for instance, in treatment of photographic film (Kumar and Takagi, 1999; Patil and Chaudhari, 2009), enzymatic combination dependent on dissolvable and cleaning agent status (Simkhada et al., 2010a), substrate disposition (Soroor et al., 2009), warm flexibility (Amoozegar et al., 2007), and production of zein hydrolysates (Miyaji et al., 2006; Dodia et al., 2008; Jaouadi et al., 2008).

\section{Alkaline Protease}

The class Bacillus is pivotal for monetarily huge stomach settling agent protease (EC.3.4.21-24.99), which is dynamic at essential $\mathrm{pH}$ broadening some place in the scope of 9 and 11 (Singhal et al., 2012).

These essential protease producers are scattered in water, soil, and uncommonly dissolvable conditions. From a collection of sources, for instance, chemical, sand soil, and slaughterhouses, confinement of stomach settling agent proteases has been communicated (Adinarayana et al., 2003). The chemical business consumes stomach settling agent proteases most bounteously, which are serine proteases with a solvent $\mathrm{pH}$ broaden (Gupta et al., 2002). These acid neutralizer serine proteases, which are easily inactivated by phenyl methane sulfonyl fluoride (PMSF), address $33 \%$ of the bit of the impetus publicize (Page and Di Cera, 2008). Stomach settling agent proteases are intriguing in their activity and keep up a predictable essential $\mathrm{pH}$ while being manhandled for different subtleties in drug, sustenance, and other related endeavors (Banerjee et al., 1999; Joo et al., 2002, 2004; Dias et al., 2008). A sweeping extent of employments of these stomach settling agent proteases are getting more thought from experts with the assumption for discovering new strains with exceptional properties and liberal activity (Najafi et al., 2005; Saeki et al., 2007). It is represented that for dehairing of animal skin and stows away, Bacillus sp. give the ideal hydrolytic, elastolytic, and keratinolytic properties (Bhaskar et al., 2007; Deng et al., 2010; Shankar et al., 2011). These Bacillus strains have been fiscally mishandled the world over due to the enormous proportions of compound transmitted with high enzymatic development (Jacobs, 1995; Ito et al., 1998; Yang, et al., 2000; Ask et al., 2003). Though essential proteases are conveyed by different 
sources (Ellaiah et al., 2002; Prakasham et al., 2005), with the extending solicitation of protease on the lookout, and for costsufficiency, simply those strains that show more conspicuous yield with hyperactivity will be recognized in the current biotechnological movement (Kumar, et al., 2012). Two fundamental sorts of acid neutralizer proteases, for instance, subtilisin Carlsberg and subtilisin novo are gained from Bacillus sp., which can be used as a mechanical compound to convey zein hydrolysates (Miyaji et al., 2006). In halophilic sources, unmistakable microbial sp. radiating serine essential proteases are similarly itemized (Vijayaraghavan et al., 2012). The entomopathogenic bacterium Photorhabdus sp. strain EK1 (PhPrtPI) containing $\mathrm{Ca} 2+$ stomach settling agent protease is masterminded as a metalloprotease. Owing to its extensive territory identity with different proteins and peptides, it is recommended that PhPrtPI offers enhancements to the nematodes by debasement of frightening little creature tissues (Soroor et al., 2009). A Salinivibrio sp. strain, AF-2004, produces metallotype protease with a reasonable warm obstruction and a broad extent of $\mathrm{pH}(5.0-10.0)$. It is an enthusiastically recommended strain on account of its warm and halophilic properties (Amoozegar et al., 2007). Another strain, Bacillus clausii, is in like manner recommended for use at a business scale for the making of dissolvable protease with the use of peptone, $\mathrm{Cu}$, and fructose as the sole wellspring of imperativeness. The ideal $\mathrm{pH}$ and temperature endorsed is $8-9$ and $37-40^{\circ} \mathrm{C}$, independently (Vadlamani and Parcha, 2011). A strain of Bacillus sp., MPTK 712, separated from dairy slush making acid neutralizer protease shows an amicable relationship with marine shipworms (Greene et al., 1989; Kumar, et al., 2012). Extraordinarily phenomenal microorganisms, for instance, Kurthiaspiroforme are also fit for conveying essential protease (Amoozegar et al., 2007). Some fundamental serine proteases saw by goat skin metagenomics library exhibits homology to peptidases (Vadlamani and Parcha, 2011) and Cryptococcus aureus shows incredible bioactivity with ideal temperature $\left(45-50^{\circ} \mathrm{C}\right)$ and $\mathrm{pH}$ (9-10) (Kumar, et al., 2012). Different mushrooms conveying dissolvable protease are also declared (Pushpam et al., 2011). Inferable from the fame of proteases in the overall market, the mission for proteases has hugely extended, as they are discovered any place in nature, to be explicit, in plants, animals, and life forms. Nevertheless, making of plant proteases, for instance, bromelain, keratinases, and ficin, is dreary (Rani et al., 2012). The animal proteases, for instance, pancreatic, trypsin, pepsin, chymotrypsin, and renin are conveyed and organized in unadulterated construction in tremendous sums (Weaver et al., 1977; Boyer and Krebs, 1986). The formation of proteases from animal sources is missing to fulfill the advanced interest all throughout the planet; thusly, specialists have extended their investigation of conveying protease from bacterial sources (Table1). Inferable from the wide reach biochemical combination and straightforward inherited control, living beings produce an exceptionally promising number of proteases (Kuhad et al., 2011). Among different sources, for instance, plants, animals, and microorganisms, proteases are overall conveyed by microbial sources. Among creatures, Bacillus sp. are broadly perused for protease creation in an immense extension, and they are abused in various organizations like cowhide, cleaning agent, drugs, and material; some infectious species like Aspergillus sp. have been perused totally for the production of dissolvable protease (Singhal et al., 2012; Singh et al., 2016; Rehman et al., 2017). An overview of living beings conveying proteases is given underneath. Halophilic synthetic substances are getting more thought in biotechnological 
applications as a result of their warm strength and ability to hold development under high concern from common solvents beside pyridine, which quells protease activity. The protein practices proceeded as before up to $80 \%$ even at 50,55 , and $60^{\circ} \mathrm{C}$ for at any rate 30 min (Xue et al., 2012).

Solvent protease of microbial sources is strikingly consistent, especially powerful, and made favorably at a tremendous degree in an all the more monetarily keen manner (Asha, Palaniswamy 2018). Inferable from higher development and more prominent adequacy at essential $\mathrm{pH}$, the substance has pulled in enormous business energy for certain fields. Though solvent protease is made by a tremendous number of microorganisms; in any case, the journey for high yielding novel strains and progression for getting more yields are continually needed. Thusly, the place of the flow research work was to look and choose high yielding strains and to upgrade the physicochemical boundaries for better yield of acid neutralizer protease. An amount of 09 protease positive disconnects were obtained from the rhizosphere of various collect plants, for instance, nut (Arachis hypogaea), cotton (Gossypium hirsutum), banana (Musa acuminata) and papaya (Carica papaya). Two of these limits, to be explicit HP_RZ17 and HP_RZ19 conveyed an ample proportion of protease. These isolates were subsequently perceived as Bacillus cereus HPRZ17 and Paenibacillus xylanilyticus HPRZ19. (Akinrinlola, et al., 2018; Arfaoui, 2019). The effect of various physicochemical components were concentrated by each factor thus (OVAT) approach where only one factor was changed keeping various segments predictable and the results were verifiably destitute down using the Understudy's t test. The upgraded show achieved a 2.45 and 3.04-cover increase in the formation of protease by $B$. cereus HP_RZ17 and $P$. xylanilyticus HP_RZ19, exclusively. (Jadhav, 2020; El-Sayed et al.,2019; Farzand An et al.,2019; Wang, et al.,2019).

Creation of proteases with profitable credits of biotechnological energy from novel strain is basic. Hence, in this assessment, an acid neutralizer serine protease made by Bacillus cereus strain S8 (MTCC NO 11901) was sifted and depicted. The stomach settling agent protease was scrubbed by ammonium sulfate precipitation (half), molecule exchange (DEAE-Cellulose) and gel filtration (Sephadex G-100) chromatographic techniques. As a result of this disinfecting, a protein with unequivocal activity of $300 \mathrm{U} / \mathrm{mg}$ protein was gotten with sterilization wrinkle 17.04 and recovery level of $34.6 \%$. The nuclear heap of the cleaned protease was settled using SDS-PAGE under nondiminishing $(71 \mathrm{kDa})$ and diminishing conditions (35 kDa and $22 \mathrm{kDa}$ ). Zymogram assessment revealed that proteolytic activity was simply associated with $22 \mathrm{kDa}$. These results show that presence of the protein as dimer in its neighborhood state. The nuclear heap of the protease $(22 \mathrm{kDa})$ was similarly constrained by gel filtration (Sephadex G-200) chromatography and it was resolved as $21.8 \mathrm{kDa}$. The ideal development of the protease was seen at $\mathrm{pH} 10.0$ and temperature $70{ }^{\circ} \mathrm{C}$ with amazing security towards $\mathrm{pH}$ and temperature with casein as a specific substrate. The impetus was completely subdued by PMSF and TLCK exhibiting that it is a serine protease of trypsin type. The protein shows a mind boggling strength towards regular solvents, oxidizing and whitening administrators and it is conversely affected by $\mathrm{Li} 2+$ and $\mathrm{Co} 2+$ metal particles. The purified protein was moreover depicted by Lattice Helped Laser Desorption Ionization/Mass Spectroscopy (MALDI/MS) examination which reveals that hard and fast number of amino acids is 208 with isoelectric point 9.52 . Potential application scope of microbial proteases for immaculate and green mechanical creation (Satbir Singh 2017). Mixtures are the establishments of 
assimilation and involve the critical justification presence of life. In any case, actually impetuses are being entangled in various present day systems taking into account their specific and fast movement for capable bioconversion of substrate to thing, and their ability to save unrefined materials, imperativeness and engineered substances for various amassing structures. Proteins are considered as condition pleasing (green) engineered mixtures that may perhaps help replacing absolutely or decreasing the usage of perilous manufactured substances for mechanical methodology, in this way promising conservative creation and gathering. Among various present day impetuses microbial proteases order the world synthetic market due to their multi-layered application potential in changed bioindustries like sustenance, drug, material, photographic, calfskin and cleaning agent. Promising employments of proteases in rustic territory for instance may fuse biocontrol of disturbances, degumming of silk, explicit delignification of hemp and downy getting ready. Regardless, for productive mechanical applications the proteases should be adequately solid to suit the strategy conditions which are usually hostile. Proteases expected for present day applications should have activity and relentlessness over wide extent of temperature and $\mathrm{pH}$ limits for postponed time periods and even inside seeing distinctive likely synthetic inhibitors. Of various microbial proteases those from Bacillus spp. have exceptional vitality considering the way that the last are known for their ability to convey sturdy synthetic substances that may have fittingness for current system conditions. The current article presents an interpretive layout of the progressing headways on application ability of proteases for various organizations.

Catalyst driven modern cycles are the most proper options in contrast to drawn-out, costly and dirtying conventional techniques.
Microbial proteases, particularly from Bacillus spp., have hugely been abused and comprised the spine for a few enterprises. The Bacillus spp. have the likely ability to create modernly appropriate chemicals which have polyextremotolerance, for example capacity to withstand limits of $\mathrm{pH}$, temperatures, presence of natural solvents and an assortment of other protein inhibitors. Accordingly, compounds from Bacillus spp. meet the modern interaction models. It is appropriate to allude Bacillus spp. as 'microbial manufacturing plants' for modern proteins. Use of proteins in cleansers guarantees eco-accommodating modern cycles which include diminished utilization of synthetic substances like cleansers, surfactants, dye, oxidizing and chelating specialists in the cleanser definition. Expansion of compounds in cleansers expands their washing adequacy, particularly for soil/residue of natural inception. Besides, utilization of compounds assists washing with being executed at lower temperatures, hence saving energy and climate. Use of chemicals in cowhide preparing system makes it more effective, eco-favorable and more secure, for example liberated from sulfide and chromium utilization. Enzymatic bioprocessing of keratin squanders visualizes eco-accommodating and manageable valorization of squanders to abundance and offers colossal potential for food, feed and corrective ventures. Use of proteases in cowhide and material industry improves the interaction economy as well as improves item quality and makes the cycles eco-kind and more effective. Protease application in silk and fleece ventures guarantees top notch silk/fleece and a more secure and eco-accommodating cycle. Use of proteases assists creating with greening measure for silver extraction from X-beam films, in this way relieving the tremendous natural contamination because of regular cycle. Microbial proteases may possibly be created as explicit therapeutics for prion infections in people and creatures. Microbial 
proteases are being examined for improvement of potential thrombolytic specialists considering the significant expense and unfortunate symptoms of the accessible chemotherapeutics. Proteases might be created as potential biocontrol specialists that may help relieving ecological contamination because of compound based pesticides. Subsequently, effective commercialization of proteases for a few biotechnological measures in enterprises makes ready for advancement of perfect, green and manageable cycles.

Besides, ongoing headways in the space of atomic science and protein designing should be misused to create novel/customized chemicals with more prominent efficacies under winning modern cycle microenvironments. Despite the fact that proteases are broadly applied proteins in a few areas of modern biotechnology, further examination is needed for investigating the full application capability of proteases. A few cycles like peptide union and sequencing, absorption of undesirable proteins, cell refined and tissue separation, planning of recombinant immunizer pieces, investigation of design work connections, expulsion of fondness labels and proteolytic processing of proteins, require tremendous exploration driving force. Additionally, with the use of recombinant DNA innovation and protein designing organisms can be controlled to improve the creation of explicit high need mechanical compounds. Extremophilic living beings could be abused for creation of cycle appropriate novel catalysts. Moreover, sub-atomic complexities of components required for utilization of proteases in assorted cycles need examination. Climate evaluation instruments like life cycle appraisal, carbon impression, ecological effect evaluation, a worldwide temperature alteration, fermentation, eutrophication and photochemical ozone arrangement could be utilized for deciding the effect of cleaner enzymatic cycles instead of customary cycles.

\section{Microbial Proteases used in Industry}

Proteases of microbial source are viewed as the most critical hydrolytic compounds, while soluble proteases are positioned the most noteworthy in the enzyme market (Mahajan et al., 2016). Interest in contemplating the proteases has expanded not just because of the guideline of various metabolic cycles yet additionally because of the significant use in modern local area. The microorganisms delivering considerable quantities of extracellular proteases are of incredible significance for the business, and few results of antacid protease are effectively advertised (Gupta et al., 2002; Gupta and Ramnani, 2006; Vijayaraghavan et al., 2014). Microbial proteases have various applications in various ventures recorded underneath.

\section{Protein Hydrolysis}

In the food business, proteases are used for modification, palatability, and capacity life of all accessible wellsprings of proteins. High healthy benefit arrangements of protein hydrolysates are accomplished by the utilization of basic proteases. In meat tenderization, antacid proteases of microbial beginning are critical (Rao et al., 1998; Sumantha et al., 2006).

\section{Food and Feedstuff Industry}

During cheddar creation from milk, proteases are added to hydrolyze kappa casein to forestall coagulation by settling micelle development. In the preparing business, for speedier readiness of mixture, its gluten is incompletely hydrolyzed by a warmth labile parasitic protease due to its initial inactivation in ensuing heating. Protein hydrolysate readiness with high dietary benefit has been cultivated by the expansion of microbial basic proteases. The bioactive peptides assume a significant part in different drug arrangements 
and as likely atoms under pressure natural conditions (Figure 1). This planning of hydrolysate is essential in newborn child food detailing and stronghold of soda pops and squeezes (Singhal et al., 2012; Singh et al., 2016).

The mackerel hydrolysates helped in the hydrolysis of protein particles into free amino acids including carosine, anserine, and other little peptides using proteases. The hydrolysis of proteins into amino acids caused the arrangement of cancer prevention agents that hinder autoxidation of linoleic corrosive and the rummaging impacts for a,a-diphenyl-bpicrylhydrazyl free revolutionaries (Wu et al., 2003; Li et al., 2008; Gómez-Guillén et al., 2011). It was tracked down that the long peptides with 1,400 Da sub-atomic weight were more grounded cell reinforcements as contrasted and more modest peptides with sub-atomic loads of 200 to 900 Da (Clemente, 2000; Foegeding et al., 2002; Tavano, 2013). It has been tracked down that the arrangement of broad protein hydrolysates through consecutive activities of exoproteases and endopeptidases combined with the delivery and advancement of the post-hydrolysis measures was considered as the most proficient approach to create protein hydrolysates that showed all around characterized attributes during protein hydrolysis (Sarmadi and Ismail, 2010; Chalamaiah et al., 2012; He et al., 2013; Force et al., 2013). The bioactive peptide delivered from the hydrolysis of different food proteins assumes a significant part as cancer prevention agents in cell (Thiansilakul et al., 2007; Nalinanon et al., 2011; Kittiphattanabawon et al., 2012). The protein hydrolysates showed incredible solvency, in view of which the cell reinforcement exercises of protein hydrosylates were improved (Kumar N. S. et al., 2012; Intarasirisawat et al., 2013; Chi et al., 2015). The bioactive peptides show anticalmodulin, anticancer, and hypocholesterolemic properties, and there are additionally multifunctional properties of the food-protein-inferred peptides (Phoenix et al., 2012; Nicolia et al., 2014; Udenigwe, 2014; Nongonierma and FitzGerald, 2015; Agyei et al., 2016).

\section{Squander the Executives}

The utilization of synthetics in ventures is inconvenient to the climate and the environmental factors. This risky utilization of synthetic compounds asks for an option ecofriendly route for the treatment of waste administration. Plumes of poultry containing an exceptionally unbending keratin structure represents $5 \%$ of the body weight and is a rich wellspring of proteins for feed and food. Poultry waste can be debased into feed and food by the keratinolytic interaction (Neklyudov et al., 2000; Lasekan et al., 2013).

For depilation and cleaning of hairs from channels and stopped up pipes, a detailing containing hydrolytic compounds secluded from B. subtilis, B. amyloliquefaciens, and Streptomyces sp. has been arranged and protected as Genex (Lasekan et al., 2013).

\section{Cowhide Industry}

Expanded utilization of soluble protease at arising calfskin ventures is because of the elastolytic and keratinolytic movement. These persuasive properties of basic protease are exceptionally successful in calfskin preparing enterprises. The specific employments of protease are discovered to be applicable in the splashing, bating, and dehairing period of getting ready skin and covers up. Annihilation of undesirable shades by enzymatic estimates helps in clean conceal creation.

Enzymatic procedures of pancreatic proteases depend on the bating framework. Microbial basic proteases have gotten extremely famous in calfskin businesses (Takami et al., 1992; Brandelli et al., 2010). 
Table.1 Protease from bacterial sources

\begin{tabular}{|c|c|c|c|}
\hline Organism & $\begin{array}{c}\text { Molecular weight, } \mathrm{pH} \text { and } \\
\text { temperature }\end{array}$ & Utility and Activity & References \\
\hline B. subtilis $B-12$ & $29 \mathrm{kDa}, \mathrm{pH} 8.0$ and $40^{\circ} \mathrm{C}$ & Enzyme activated by $\mathrm{Zn}^{2+}$ & Wang et al., (2019) \\
\hline B. subtilis LD-8547 & $30 \mathrm{kDa}, \mathrm{pH} 8.0$ and $50^{\circ} \mathrm{C}$ & PMSF inhibited activity & Wang et al., (2019) \\
\hline B. subtilis DC33 & $30 \mathrm{kDa}, \mathrm{pH} 8.0$ and $60^{\circ} \mathrm{C}$ & $\begin{array}{l}\text { Soybean trypsin inhibitor } \\
\text { inhibited activity }\end{array}$ & Wang et al., (2019) \\
\hline B. subtilis A26 & $28 \mathrm{kDa}, \mathrm{pH} 9.0$ and $60^{\circ} \mathrm{C}$ & Activity totally lost with PMSF & Agrebi et al., (2009) \\
\hline B. sphaericus & $18.6 \mathrm{kd}$ & $\begin{array}{c}\text { Fibrinolytic activity was } \\
\text { similar to that of streptokinase } \\
\text { Balaraman }\end{array}$ & $\begin{array}{l}\text { Balaraman and Prabakaran } \\
\text { (2007) }\end{array}$ \\
\hline B. subtilis ICTF-1 & $28 \mathrm{kDa}, \mathrm{pH} 9.0$ and $50^{\circ} \mathrm{C}$ & $\begin{array}{c}\text { Activated by } \mathrm{Ca} 2 \text { ? and } \\
\text { inhibited by } \mathrm{Zn}_{2}, \mathrm{Fe}_{2}, \mathrm{Hg}_{2} \text { and } \\
\text { PMSF }\end{array}$ & $\begin{array}{l}\text { Mahajan et al., } \\
\text { (2016) }\end{array}$ \\
\hline $\begin{array}{c}\text { B.amyloliquefaciens } \\
\text { CH86-1 }\end{array}$ & $27 \mathrm{kDa}$ & $\begin{array}{l}\text { Gene apr E86-1 was expressed } \\
\text { in B.subtilis }\end{array}$ & Lee et al., (2010) \\
\hline $\begin{array}{c}\text { B.amyloliquefaciens } \\
\text { MJ5-41 }\end{array}$ & $27 \mathrm{kDa}, \mathrm{pH} 7.0$ and $45^{2} \mathrm{C}$ & $\begin{array}{l}\text { Gene apr E5-41 was expressed } \\
\text { in B.subtilis }\end{array}$ & Jo et al., (2011b) \\
\hline B. subtilis EAG-2 & $27 \mathrm{kDa}, \mathrm{pH} 8.5$ and $65^{\circ} \mathrm{C}$ & Activity reduced by PMSF & Ghafoor and Hasnain (2010) \\
\hline $\begin{array}{l}\text { B. amyloliquefaciens } \\
\text { CH5I }\end{array}$ & $\begin{array}{c}\text { Cheonggukjang } 27 \mathrm{kDa}, \mathrm{pH} \\
6.0 \text { and } 45^{\circ} \mathrm{C}\end{array}$ & $\begin{array}{l}\text { Tryptic soy broth was best for } \\
\text { enzyme production }\end{array}$ & Kim et al. (2009) \\
\hline B. subtilis $\mathrm{K} 42$ & $20.5 \mathrm{kDa}, \mathrm{pH} 9.4$ and $40^{\circ} \mathrm{C}$ & Organic solvent stable & Hassanein et al., (2011) \\
\hline B. licheniformis KJ-31 & $37 \mathrm{kDa}, \mathrm{pH} 9.0$ and $40^{\circ} \mathrm{C}$ & Activity inhibited by PMSF & Hwang et al., (2007) \\
\hline B. subtilis GBRC1 & $\begin{array}{l}24.6-33.0 \mathrm{kDa}, \mathrm{pH} 7.0-12 \\
\text { and } 50^{\circ} \mathrm{C}\end{array}$ & Inhibited by PMSF & Jayalakshmi et al., (2012) \\
\hline
\end{tabular}

Fig.1 Bacterial colony of Bacillus species

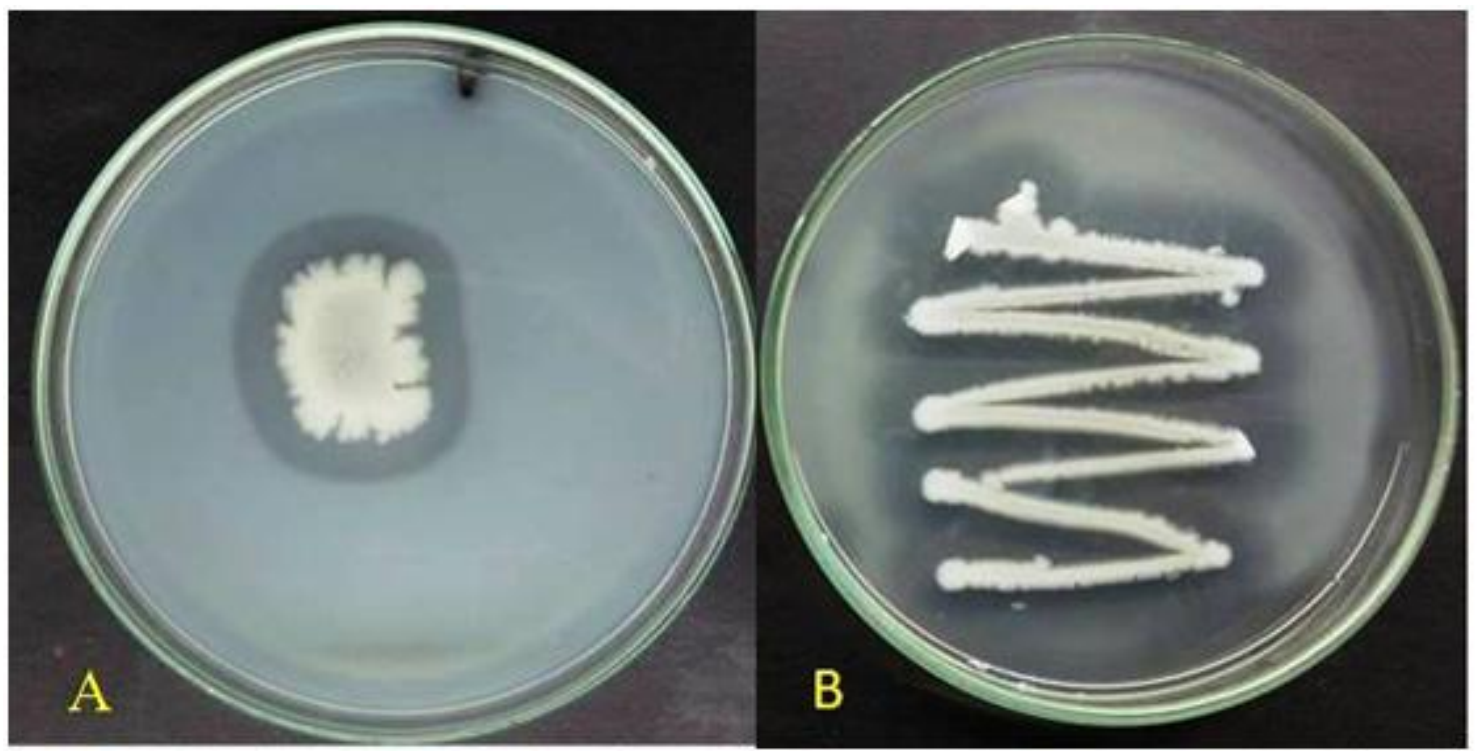


Fig.2 Schematic representation of potential applications of proteases

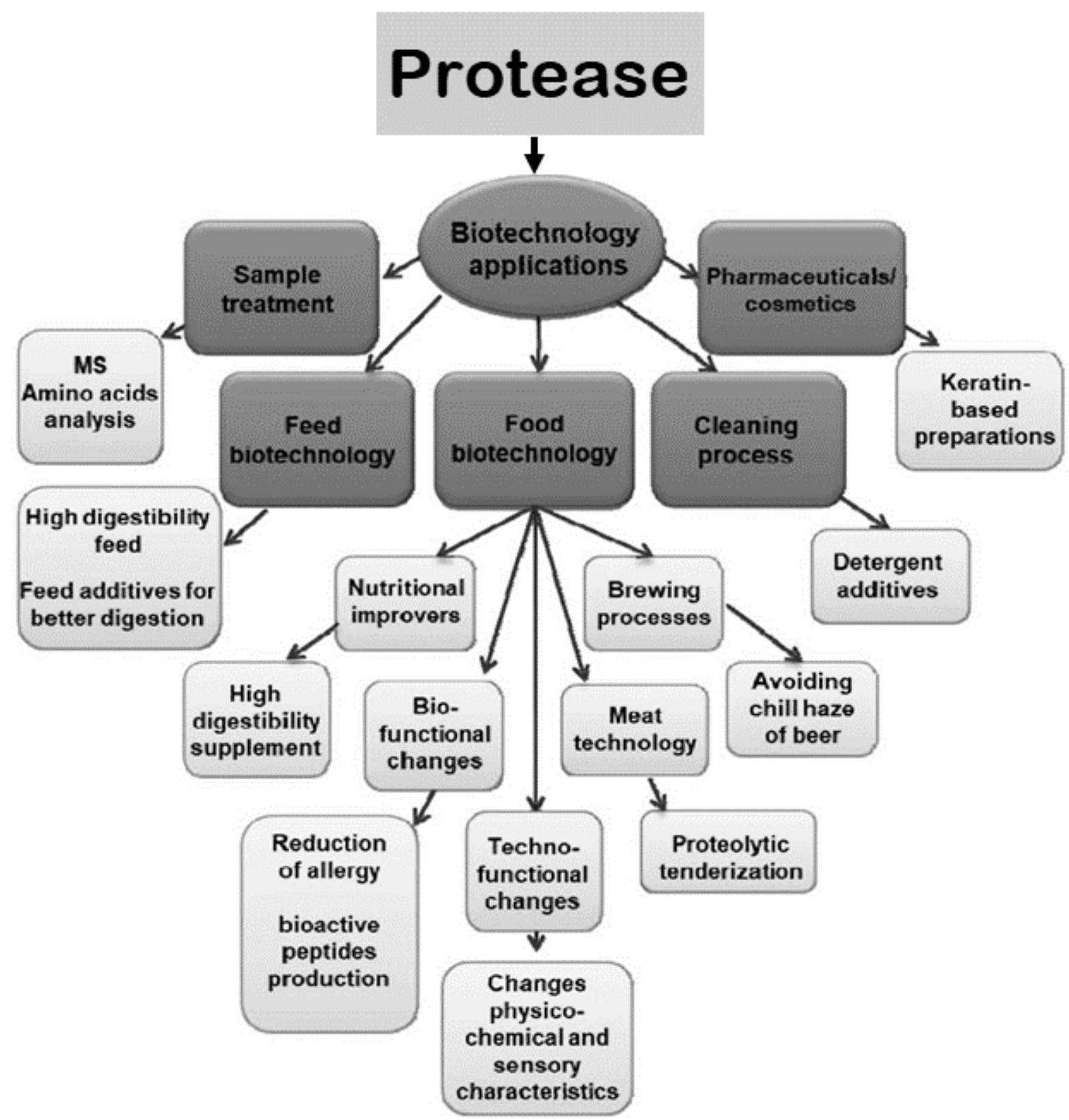

\section{Cleaning Industry}

Proteases have been generally utilized at business scale in the cleanser business. The different items in the cleanser business containing proteases as a fundamental part or fixing have been utilized for cleaning of family clothing, false teeth, or contact focal points. Of the all out offer of catalysts, the usage of proteases in the cleanser business represents $\sim 20 \%$. In 1913, the absolute first enzymatic planning, "Brunus," was readied comprising of rough pancreatic concentrate and sodium carbonate. This enzymatic planning was first advertised in 1956 with a business trademark of BIO-40. Alcalase with a trademark of BIOTEX created by B. licheniformis was brought into the market by 
Novo industry A/S in 1965. Protease created by B. cereus BM1 was accounted for as a decent cleanser fixing and shows stable action in an answer of $10 \%(\mathrm{w} / \mathrm{v})$ business cleanser (Fabs Great), which recommends its business utilization. Isoelectric point is significant for the choice of proteases for cleanser arrangement. Proteases display striking outcomes when $\mathrm{pH}$ and PI points of these chemicals are roughly accompanying. There are a couple of different boundaries, like similarity with surfactants, dyes and scents (Bayoudh et al., 2000), great activity,optimum $\mathrm{pH}$, and temperature ionic strength, solidness and evacuation capability of stain, which have additionally been considered for the decision of cleanser proteases. Customarily, cleansers work at high temperature yet the interest has been expanded to look and distinguish soluble proteases working in a wide scope of temperature. For the most part, within the sight of dying or oxidizing specialist, industrially accessible proteases are not steady. As of late, rDNA innovation has been joined to create bioengineered cleanser proteases with more noteworthy strength and time span of usability. By the utilization of protein designing, the substitution of few explicit amino corrosive deposits has been read for blanch and oxidation strength of proteases. Proteases have been utilized as clothing cleanser as well as dishwashing and cleaning cleansers both in institutional and modern areas (Bornscheuer et al., 2012).

Fig.3 Protein hydrolysis using protease

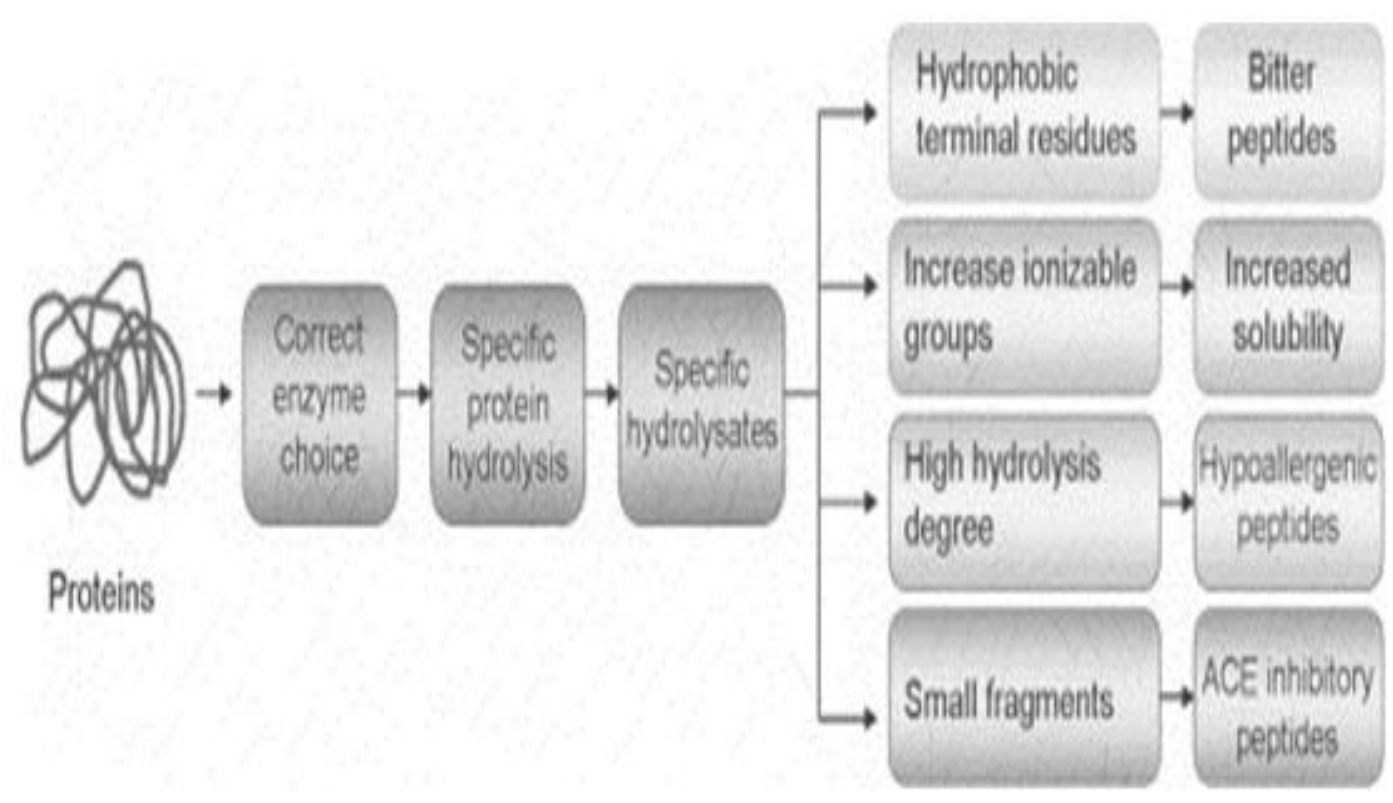

\section{Photographic Industry}

Soluble proteases delivered by B. subtilis, Streptomyces avermectnus, and Conidiobolus coronatus have been effectively answered to recuperate silver from X-beam films, guaranteeing that the cycle is eco-more amicable over the utilization of synthetic compounds (Godfrey and West, 1996b; Wolff et al., 1996; Yang, et al., 2000). Silver recuperation by the effective utilization of thermally stable freak basic protease delivered by Bacillus sp. B21-2 has additionally been accounted for its latent capacity (Dhawan and Kaur, 2007; Araujo et al., 2008). 


\section{Element Industry}

Different soluble proteases creating microorganisms, for example, Bacillus pseudofirus SVB1, Aspergillus flavus and Pseudomonas aeruginosa PseA showed generous outcomes in peptide amalgamation because of solidness in natural solvents (Nakiboglu et al., 2001; Ahmed et al., 2008; Shankar et al., 2010). Some antacid protease delivering types of Bacillus and Streptomyces in the water framework are dynamic contender for peptide and natural blend (Yadav et al., 2015).

\section{Silk Degumming}

A proteinaceous substance, "sericin or silk gum," should be eliminated by the interaction of degumming from crude silk in a basic arrangement of cleanser traditionally. Basic protease is the most ideal decision to eliminate sericin while not assaulting the fiber. It has been demonstrated that fiber break isn't amiable, and silk strings are discovered to be a lot more grounded than when past customary medicines were utilized (Yadav et al., 2011; da Silva et al., 2017; Radha et al., 2017).

\section{Medical Field}

With the progression of time, researchers have tracked down the wide utilization of proteases in clinical field effectively. In medication, various equations, like bandage, non-woven tissues, and salve sythesis containing antacid proteases delivered by $B$. subtilis show promising helpful properties (Awad et al., 2013). Certain lytic protein lack conditions are analyzed to be helped by an oral organization of antacid proteases (Joshi and Satyanarayana, 2013). It has been accounted for that fibrin corruption has been accomplished by antacid fibrinolytic proteases. The utilization of this fibrinolytic chemical proposes its future application as an anticancer medication and in thrombolytic treatment (Jaouadi et al., 2011, 2012). Moderate delivery dose form preparation containing collagenases with basic proteases is widely utilized in restorative applications. The hydrolysis of collagen by the compound frees low-sub-atomic weight peptides with no amino corrosive delivery for remedial use (Suwannaphan et al., 2017). For the treatment of different infections, like consumes, carbuncles, furuncles, and wounds, a planning of elastoterase immobilized on bandag is utilized (Palanivel et al., 2013).

\section{Different lookout of Proteases}

Aside from essential modern utilization of proteases, they are being utilized for the cleavage of peptide attach to clarify the relationship among construction and capacity of peptides and proteins. Soluble proteases disconnected from Vibrio metschnikovii RH530 can be utilized as an option in contrast to proteinase $\mathrm{K}$ in DNA confinement (Narasimhan et al., 2015; Vijayaraghavan and Vincent, 2015). Subsequently, the proteases can be seen as an option in contrast to numerous synthetic compounds associated with different biochemical and physiological cycles.

In conclusion, the current survey centers round the examination among various proteases and therefore the current issues looked during creation and application at the mechanical level. Unraveling these issues would empower us to advance microbial proteases monetarily and industrially all throughout the earth. Since the approach of enzymology, catalysts are extensively employed in a large scope of companies like material, drugs, cowhide, food, and cleanser. Internationally, its utilization and creation are expanding with the use of modest crude material and by fusing hereditary control. Presently, there's a dire requirement for the use of such innovation that guarantees cleaner 
creation as an option in contrast to the use of dangerous synthetic compounds, like proteases. The higher-ups and also the state should assume the liability of empowering financial backers for a cleaner creation to alleviate the danger of eco-contamination.

\section{References}

Adinarayana, K., Ellaiah, P., and Prasad, D. S. (2003). Purification and partial characterization of thermostable serine alkaline protease from a newly isolated.

Adrio, J., and Demain, A. (2014). Microbial enzymes: tools for biotechnological processes. Biomolecules 4, 117-139. doi: 10.3390/biom4010117.

Agyei D., Ongkudon C. M., Wei C. Y., Chan A. S., Danquah M. K. (2016). Bioprocess challenges to the isolation and purification of bioactive peptides. Food Bioprod. Process. 98, 244-256.

Ahmed S. A., Al-Domany R. A., El-Shayeb N. M., Radwan H. H., Saleh S. A. (2008). Optimization, immobilization of extracellular alkaline protease and characterization of its enzymatic properties. Res. J. Agric. Biol. Sci. 4, 434-446.

Akinrinlola RJ, Yuen GY, Drijber RA, Adesemoye AO (2018) Evaluation of Bacillus strains for plant growth promotion and predictability of efficacy by in vitro physiological traits. Int $\mathbf{J}$ Microbiol 2018:5686874.

Ali N., Ullah N., Qasim M., Rahman H., Khan S. N., Sadig A., et al. . (2016). Molecular characterization and growth optimization of halotolerant protease producing Bacillus subtilis Strain BLK-1.5 isolated from salt mines of Karak, Pakistan. Extremophiles 20, 395-402.

Amoozegar, M. A., Fatemi, A. Z., Karbalaei-Heidari, H. R., and Razavi, M. R. (2007). Production of an extracellular alkaline metalloprotease from a newly isolated, moderately halophile, Salinivibrio sp. strain AF-2004. Microbiol. Res. 162, 369377.

Araujo R., Casal M., Cavaco-Paulo A. (2008). Application of enzymes for textile fibres processing. Biocatal. Biotransformation 26, 332349.

Arfaoui M, Vallance J, Bruez E, Rezgui A, Melki I, Chebil S, Sadfi-Zouaoui N, Rey P (2019) Isolation, identification and in vitro characterization of grapevine rhizobacteria to control ochratoxigenic Aspergillus spp. on grapes. Biol Control 129:201-211.

Asha B, Palaniswamy M (2018) Optimization of alkaline protease production by Bacillus cereus FT 1 isolated from soil. J Appl Pharm Sci 8(02):119-127.

Awad, H. M., Mostafa, E.-S. E., Saad, M. M., Selim, M. H., and Hassan, H. M. (2013). Partial purification and characterization of extracellular protease from a halophilic and thermotolerant strain Streptomyces pseudogrisiolus NRC-15. Indian. J. Biochem. Biophys. 50, 305-311.

Balaraman K, Prabakaran G. Production \& purification of a fibrinolytic enzyme (thrombinase) from Bacillus sphaericus. Indian $J$ Med Res. 2007;126(5):459-64.

Banerjee, G., and Ray, A. K. (2017). Impact of microbial proteases on Biotechnological industries. Biotechnol. Genet. Eng. Rev. 33, 119143. doi: $10.1080 / 02648725.2017 .1408256$

Bayoudh A., Gharsallah N., Chamkha M., Dhouib A., Ammar S., Nasri M. (2000). Purification and characterization of an alkaline protease from Pseudomonas aeruginosa MN1.J. Ind. Microbiol. Biotechnol. 24, 291-295.

Beg Q. K., Gupta R. (2003). Purification and characterization of an oxidation-stable, thioldependent serine alkaline protease from Bacillus mojavensis. Enzyme Microb. Technol. 32, 294304.

Bhaskar N., Sudeepa E., Rashmi H., Selvi A. T. (2007). Partial purification and characterization of protease of Bacillus proteolyticus CFR3001 isolated from fish processing waste and its antibacterial activities. Bioresour. Technol. 98, 2758-2764.

Bornscheuer U., Huisman G., Kazlauskas R., Lutz S., Moore J., Robins K. (2012). Engineering the third wave of biocatalysis. Nature 485:185.

Brandelli A., Daroit D. J., Riffel A. (2010). Biochemical features of microbial keratinases and their production and applications. Appl. Microbiol. Biotechnol. 85, 1735-1750.

Chalamaiah M., Hemalatha R., Jyothirmayi T. (2012). Fish protein hydrolysates: Proximate composition, amino acid composition, antioxidant activities and applications: a review. Food Chem. 135, 3020-3038.

Chi C.-F., Wang B., Wang Y.-M., Zhang B., Deng S.G. (2015). Isolation and characterization of three antioxidant peptides from protein hydrolysate of bluefin leatherjacket (Navodonseptentrionalis) heads. J. Funct. Foods 12, 1-10.

da Silva O. S., Gomes M. H. G., de Oliveira R. L., Porto A. L. F., Converti A., Porto T. S. (2017). Partitioning and extraction protease from Aspergillus tamarii URM4634 using PEGcitrate aqueous two-phase systems. Biocatal. 
Agric. Biotechnol. 91, 68-73.

Das G., Prasad M. (2010). Isolation, purification \& mass production of protease enzyme from Bacillus subtilis. Int. Res. J. Microbiol. 1, 26-31.

Deng A., Wu J., Zhang Y., Zhang G., Wen T. (2010). Purification and characterization of a surfactant-stable high-alkaline protease from Bacillus sp. B001. Bioresour. Technol. 101, 7100-7106.

Dhawan S., Kaur J. (2007). Microbial mannanases: an overview of production and applications. Crit. Rev. Biotechnol. 27, 197-216.

Dias D. R., Vilela D. M., Silvestre M. P. C., Schwan R. F. (2008). Alkaline protease from Bacillus sp. isolated from coffee bean grown on cheese whey. World J. Microbiol. Biotechnol. 24, 20272034.

Dodia M., Rawal C., Bhimani H., Joshi R., Khare S., Singh S. P. (2008). Purification and stability characteristics of an alkaline serine protease from a newly isolated Haloalkaliphilic bacterium sp. AH-6. J. Ind. Microbiol. Biotechnol. 35, 121-131.

El-Sayed M, Nassar O, Nasr H, Kobisi AEN (2019) Efficacy of thermophilic soilisolated Paenibacillus sp. NBR10 as a chitinolytic and biocontrol bacterium - in vitro study. Egypt $\mathrm{J}$ Bot 59(1):195-208.

Farzand A, Moosa A, Zubair M, Khan AR, Hanif A, Tahir HAS, Gao X (2019) Marker-assisted detection and LC-MS analysis of antimicrobial compounds in different Bacillus strains and their antifungal effect on Sclerotinia sclerotiorum. Biol Control 133:91-102.

Ghafoor A, Hasnain S (2010) Purification and characterization of an extracellular protease from Bacillus subtilis EAG-2 strain isolated from ornamental plant nursery. Pol J Microbiol 59:107-112.

Hassanein WA, Kotb E, Awny NM, El-Zawahry YA (2011) Fibrinolysis and anticoagulant potential of a metallo protease produced by Bacillus subtilis K42. J Biosci 36:773-779.

He R., Girgih A. T., Malomo S. A., Ju X., Aluko R. E. (2013). Antioxidant activities of enzymatic rapeseed protein hydrolysates and the membrane ultrafiltration fractions. J. Funct. Foods 5, 219227.

Hui C, Wei R, Jiang H, Zhao Y, Xu L (2019) Characterization of the ammonification, the relevant protease production and activity in a high-efficiency ammonifier Bacillus amyloliquefaciens DT. Int BiodeteriorBiodegrad 142:11-17.

Hwang Kyung-Ju, Choi KH, Kim MJ et al (2007) Purification and characterization of a new fibrinolytic enzyme of Bacillus licheniformis $\mathrm{KJ}$ 31, isolated from Korean traditional Jeot-gal. J Microbiol Biotechnol 17:1469-1476.

Intarasirisawat R., Benjakul S., Wu J., Visessanguan W. (2013). Isolation of antioxidative and ACE inhibitory peptides from protein hydrolysate of skipjack (Katsuwana pelamis) roe.J. Funct. Foods 5, 1854-1862.

Jadhav, Hitendra\&Sonawane, M. \&Khairnar, Mitesh \& Sayyed, Riyaz. (2020). Production of alkaline protease by rhizospheric Bacillus cereus HP_RZ17 and Paenibacillus xylanilyticus HP_RZ19. Environmental Sustainability. 3. 10.

Jaouadi B., Ellouz-Chaabouni S., Rhimi M., Bejar S. (2008). Biochemical and molecular characterization of a detergent-stable serine alkaline protease from Bacillus pumilus CBS with high catalytic efficiency. Biochimie 90, 12911305.

Jayalakshmi T, Krishnamoorthy P, Ramesh Babu PB, Vidhya B (2012) Production, purification and biochemical characterization of alkaline fibrinolytic enzyme from Bacillus subtilis strainGBRC1. J Chem Pharm Res 4:5027-5031.

Joo H.-S., Kumar C. G., Park G.-C., Kim K. T., Paik S. R., Chang C.-S. (2002). Optimization of the production of an extracellular alkaline protease from Bacillus horikoshii. Process Biochem. 38, $155-159$.

Joshi S., Satyanarayana T. (2013). Characteristics and applications of a recombinant alkaline serine protease from a novel bacterium Bacillus lehensis. Bioresour. Technol. 131, 76-85.

Kim GM, Lee AR, Lee KW et al (2009) Characterization of a $27 \mathrm{kDa}$ fibrinolytic enzyme from Bacillus amyloliquefaciens CH51 isolated from Cheonggukjang. J Microbiol Biotechnol 19:997-1004.

Kittiphattanabawon P., Benjakul S., Visessanguan W., Shahidi F. (2012). Gelatin hydrolysate from blacktip shark skin prepared using papaya latex enzyme: antioxidant activity and its potential in model systems. Food Chem. 135, 1118-1126.

Kuhad R. C., Gupta R., Singh A. (2011). Microbial cellulases and their industrial applications. Enzyme Res. (2011) 2011:280696.

Kumar D. M., Premavathi V., Govindarajan N., Balakumaran M., Kalaichelvan P. (2012). Production and purification of alkaline protease from Bacillus sp. MPTK 712 isolated from dairy sludge. Global Vet. 8, 433-439.

Kumar N. S., Nazeer R., Jaiganesh R. (2012). Purification and identification of antioxidant peptides from the skin protein hydrolysate of two marine fishes, horse mackerel (Magalaspiscordyla) and croaker 
(Otolithesruber). Amino Acids 42, 1641-1649.

Lasekan A., Bakar F. A., Hashim D. (2013). Potential of chicken by-products as sources of useful biological resources. Waste Manage. 33, 552565.

Mahajan R., Chaudhari G., Chopadaa M. (2016). Report on Biotechnological applications of proteolytic enzymes from lattices of euphorbian plants. J. Appl. Biotechnol. Rep. 2, 333-337.

Miyaji T., Otta Y., Nakagawa T., Watanabe T., Niimura Y., Tomizuka N. (2006). Purification and molecular characterization of subtilisin-like alkaline protease BPP-A from Bacillus pumilus strain MS-1. Lett. Appl. Microbiol. 42, 242-247.

Nakiboglu N., Toscali D., Yaşa I. (2001). Silver recovery from waste photographic films by using enzymatic method. Turk. J. Chem. 25, 349-353.

Nalinanon S., Benjakul S., Kishimura H., Shahidi F. (2011). Functionalities and antioxidant properties of protein hydrolysates from the muscle of ornate threadfin bream treated with pepsin from skipjack tuna. Food Chem. 124, 1354-1362.

Narasimhan M. K., Chandrasekaran M., Rajesh M. (2015). Fibrinolytic enzyme production by newly isolated Bacillus cereus SRM-001 with enhanced in-vitro blood clot lysis potential. $J$. Gen. Appl. Microbiol. 61, 157-164.

Neklyudov A., Ivankin A., Berdutina A. (2000). Properties and uses of protein hydrolysates. Appl. Biochem. Microbiol. 36, 452459.

Nicolia A., Manzo A., Veronesi F., Rosellini D. (2014). An overview of the last 10 years of genetically engineered crop safety research. Crit. Rev. Biotechnol. 34, 77-88.

Nisha N., Divakaran J. (2014). Optimization of alkaline protease production from Bacillus subtilis NS isolated from sea water. Afr. J. Biotechnol. 13, 1707-1713.

Nongonierma A. B., FitzGerald R. J. (2015). The scientific evidence for the role of milk proteinderived bioactive peptides in humans: a review. $J$. Funct. Foods 17, 640-656.

Page M. J., Di Cera E. (2008). Evolution of peptidase diversity. J. Biol. Chem. 283, 30010-30014.

Palanivel P., Ashokkumar L., Balagurunathan R. (2013). Production, purification and fibrinolytic characterization of alkaline protease from extremophilic soil fungi.Int. J. Pharm. Bio. Sci. 4, 101-110.

Palsaniya P., Mishra R., Beejawat N., Sethi S., Gupta B. L. (2012). Optimization of alkaline protease production from bacteria isolated from soil. $J$. Microbiol. Biotechnol. Res. 2, 695-701.

Panda M. K., Sahu M. K., Tayung K. (2013). Isolation and characterization of a thermophilic Bacillus sp. with protease activity isolated from hot spring of Tarabalo, Odisha, India. Iran. J. Microbiol. 5:159.

Phoenix D. A., Dennison S. R., Harris F. (2012). Antimicrobial Peptides. Wiley-VCH Verlag GmbH \& Co. KGaA.

Power O., Jakeman P., FitzGerald R. (2013). Antioxidative peptides: enzymatic production, in vitro and in vivo antioxidant activity and potential applications of milk-derived antioxidative peptides. Amino acids 44, 797-820.

Pushpam P. L., Rajesh T., Gunasekaran P. (2011). Identification and characterization of alkaline serine protease from goat skin surface metagenome. AMB Express 1:3.

Radha S., Sridevi A., HimakiranBabu R., Nithya V., Prasad N., Narasimha G. (2017). Medium optimization for acid protease production from Aspergillus sps under solid state fermentation and mathematical modelling of protease activity. J. Microbiol. Biotechnol. Res. 2, 6-16.

Rani K., Rana R., Datt S. (2012). Review on latest overview of proteases. Int. J. Curr. Life Sci. 2, $12-18$.

Rehman R., Ahmed M., Siddique A., Hasan F., Hameed A., Jamal A. (2017). Catalytic role of thermostable metalloproteases from Bacillus subtilis KT004404 as dehairing and destaining agent. Appl. Biochem. Biotechnol. 181, 434-450.

Sandhya C., Sumantha A., Szakacs G., Pandey A. (2005). Comparative evaluation of neutral protease production by Aspergillus oryzae in submerged and solid-state fermentation. Process Biochem. 40, 2689-2694.

Sarmadi B.H., Ismail A. (2010). Antioxidative peptides from food proteins: a review. Peptides 31, 19491956.

Satbir Singh \&Bijender Kumar Bajaj. (2017) Potential application spectrum of microbial proteases for clean and green industrial production. Energ. Ecol. Environ. DOI 10.1007/s40974-017-0076-5.

Sathishkumar R., Ananthan G., Arun J. (2015). Production, purification and characterization of alkaline protease by ascidian associated Bacillus subtilis GA CAS8 using agricultural wastes. Biocatal. Agric. Biotechnol. 4, 214-220.

Shankar S., More S., Laxman R. S. (2010). Recovery of silver from waste $\mathrm{X}$-ray film by alkaline protease from Conidioboluscoronatus. Kathmandu Univ. J. Sci. Eng. Technol. 6, 60-69.

Shankar S., Rao M., Laxman R. S. (2011). Purification and characterization of an alkaline protease by a new strain of Beauveria sp. Process Biochem. 46, 579-585. 
Simkhada J. R., Cho S. S., Park S. J., Mander P., Choi Y. H., Lee H. J., et al. . (2010a). An oxidant-and organic solvent-resistant alkaline metalloprotease from Streptomyces olivochromogenes. Appl. Biochem. Biotechnol. 162, 1457-1470.

Singh R., Mittal A., Kumar M., Mehta P. K. (2016). Microbial protease in commercial applications. J. Pharm. Chem. Biol. Sci. 4, 365374.

Singhal P., Nigam V., Vidyarthi A. (2012). Studies on production, characterization and applications of microbial alkaline proteases. Int. J. $A d v$. Biotechnol. Res. 3, 653-669.

Suwannaphan S., Fufeungsombut E., Promboon A., Chim-Anage P. (2017). A serine protease from newly isolated Bacillus sp. for efficient silk degumming, sericin degrading and colour bleaching activities. Int. Biodeter. Biodegrad. 117, 141-149.

Tavano O. L. (2013). Protein hydrolysis using proteases: an important tool for food biotechnology. J. Mol. Catal. B Enzym. 90, 1-11.

Thiansilakul Y., Benjakul S., Shahidi F. (2007). Compositions, functional properties and antioxidative activity of protein hydrolysates prepared from round scad (Decapterusmaruadsi). Food Chem. 103, 13851394.

Udenigwe C. C. (2014). Bioinformatics approaches, prospects and challenges of food bioactive peptide research. Trends Food Sci. Technol. 36, 137-143.

Vadlamani S., Parcha S. R. (2011). Studies on industrially important alkaline protease production from locally isolated superior microbial strain from soil microorganisms. Int. J. Biotechnol. Appl. 3, 102-105.

Vijaya Raghavan P., Vincent S. P. (2015). A low cost fermentation medium for potential fibrinolytic enzyme production by a newly isolated marine bacterium, Shewanella sp. IND20. Biotechnol. Rep. 7, 135-142.

Vijayaraghavan P., Vincent S. P. (2015). A low-cost fermentation medium for potential fibrinolytic enzyme production by a newly isolated marine bacterium, Shewanella sp. IND20. Biotechnol. Rep. 7, 135-142.

Wang X, Li Q, Sui J, Zhang J, Liu Z, Du J, Xu R, Zhou Y, Liu X (2019) Isolation and characterization of antagonistic bacteria Paenibacillus jamilae HS-26 and their effects on plant growth. Biomed Res Int.

Xue B., Dunker A. K., Uversky V. N. (2012). Orderly order in protein intrinsic disorder distribution: disorder in 3500 proteomes from viruses and the three domains of life. J. Biomol. Struct. Dyn. 30, 137-149.

Yadav S. K., Bisht D., Shikha S., Darmwal N. S. (2011). Oxidant and solvent stable alkaline protease from Aspergillus flavus and its characterization. Afr. J. Biotechnol. 10, 86308640 .

Yadav S. K., Bisht D., Tiwari S., Darmwal N. S. (2015). Purification, biochemical characterization and performance evaluation of an alkaline serine protease from Aspergillus flavus MTCC 9952 mutant. Biocatal. Agric. Biotechnol. 4, 667-677.

Younes I., Rinaudo M. (2015). Chitin and chitosan preparation from marine sources. Structure, properties and applications. Marine Drugs 13, $1133-1174$.

\section{How to cite this article:}

Jitendra Malviya. 2021. Potential of Protease from Bacillus species for Biomedical and Industrial Applications. Int.J.Curr.Microbiol.App.Sci. 10(05): 560-574.

doi: https://doi.org/10.20546/ijcmas.2021.1005.063 